\title{
O IMPACTO DA GENTILEZA NAS EMPRESAS
}

\section{ARTIGO ORIGINAL}

STÉDILE, Rafael Francisco Neves ${ }^{1}$

MARTINS, Evelyn Souto ${ }^{2}$

STÉDILE, Rafael Francisco Neves. MARTINS, Evelyn Souto. O impacto da gentileza nas empresas. Revista Científica Multidisciplinar Núcleo do Conhecimento. Ano 05, Ed. 03, Vol. 01, pp. 18-56. Março de 2020. ISSN: 2448-0959, Link de acesso: https://www.nucleodoconhecimento.com.br/administracao/impacto-dagentileza

\section{RESUMO}

Este estudo investiga os impactos da gentileza nas empresas. Os conceitos e tipos de gentilezas são mostrados no referencial teórico bem como a importância da gentileza, inclusive no meio organizacional assim como as formas de estimular e disseminar a sua prática. A pesquisa empírica, realizada por meio de um questionário respondido por cem pessoas e de uma entrevista dirigida, evidencia a importância e o impacto da gentileza. Assim, os resultados serão discutidos e comparados com a teoria, destacando os reflexos do uso da gentileza, principalmente nas empresas.

Palavras-chave: Gentileza, bem-estar, produtividade, gestão, pessoas.

1 MBA em Gestão Estratégica de Pessoas; MBA em Gestão de Negócios, Controladoria e Finanças Corporativas; Graduação em Ciências Contábeis.

2 Mestrado em Gestão Empresarial. Especialização em Gestão Empresarial. Especialização em Ciências do Esporte. Graduação em Educação Física. 


\section{INTRODUÇÃO}

Harari (2015) estima que os humanos surgiram há 200 mil anos, e, desde então, as interações sociais criaram uma variedade imensurável de hábitos, costumes, regras, valores, princípios, formas de se comunicar, de se relacionar e, também, de se tratar. A humanidade se desenvolveu mais intensamente a partir do momento em que o indivíduo deixou de viver isoladamente e surgiram as primeiras sociedades, cidades e povos. O convívio em grupo promoveu crescimento e desenvolvimento para as pessoas. Algumas mazelas também surgiram, misérias, guerras. Viver em sociedade pode trazer benefícios e malefícios. Como lidar com isso de forma generalizada? Atualmente, vivemos em uma época na qual se busca potencializar tudo: o lucro, as experiências, os prazeres, o consumo, as descobertas. Melo (2017), afirma que as mudanças acontecem com uma velocidade nunca vivida pela raça humana e aumentam de forma exponencial.

As cobranças são cada vez maiores em todas as áreas das vidas das pessoas. Precisa-se estudar, trabalhar, sustentar a família etc. Quase não se tem tempo para parar e questionar o motivo disso tudo. Esse turbilhão que chamamos de vida vale a pena? Então, nos deparamos com o desafio: como crescer e evoluir em sociedade, de forma ética, trazendo progresso e felicidade a todos? O uso da gentileza pode ser a resposta para esse dilema. Harrison (2007), diz que as gentilezas tornam a conversa sobre ética mais palpável, principalmente nas empresas. A maioria das gentilezas custa quase nada e ocasionam mudanças que podem gerar resultados expressivos, criando uma cultura corporativa que ajuda a proteger as empresas de lapsos éticos, ofensas entre pessoas no local de trabalho e fraudes. Será tratado, aqui, como a gentileza pode impactar as empresas e os ambientes corporativos e o que isso pode representar para a sociedade.

\subsection{PROBLEMA}

Diante de tantos desafios de ordem social e profissional com os quais constantemente as pessoas se deparam no ambiente de trabalho e devido as exigências de ordem 
profissional cada vez maiores, tem-se a seguinte pergunta de pesquisa: qual o impacto da presença/ausência de gentileza nas empresas?

\subsection{OBJETIVOS}

\subsubsection{OBJETIVO GERAL}

Mostrar o impacto do uso da gentileza nas empresas.

\subsubsection{OBJETIVOS ESPECÍFICOS}

- Analisar o conceito e tipos de gentileza na visão de autores e especialistas no tema;

- Identificar como a gentileza impacta o dia-a-dia das pessoas e a sociedade como um todo;

- Averiguar como profissionais e clientes percebem a gentileza;

- Analisar se a gentileza, no ambiente corporativo, em relação ao gestor ou líder, tem influência nas entregas, nos resultados e como isso ocorre;

- Identificar meios de estimular o exercício da gentileza no ambiente organizacional e nas futuras gerações de profissionais.

\subsection{JUSTIFICATIVA}

A frase mais popular do pregador urbano José Datrino, mais conhecido como Profeta Gentileza, diz que "gentileza gera gentileza", porém o oposto também se aplica, a impolidez, a descortesia e a grosseria produzem essas mesmas mazelas. Estudar o impacto da gentileza nas organizações é aprender como a convivência entre as pessoas no ambiente de trabalho pode ser mais leve e agradável e qual o resultado disso, visto que as empresas são compostas por pessoas que geram resultados. Fazse necessário analisar e averiguar se o modo como essas pessoas se relacionam 
interfere diretamente no produto ou serviço entregue bem como no modo como são entregues.

\section{REFERENCIAL TEÓRICO}

\subsection{O QUE É GENTILEZA?}

Tiago (2015) comenta que a gentileza é o grande trunfo do profissional que quer fazer a diferença no mercado para atrair e fidelizar clientes e melhorar resultados, principalmente porque a falta de ética nas relações é grande, de modo que quem se relaciona com empatia, cordialidade e respeito gera atitudes superpositivas. Mais do que isso, pessoas gentis atraem fidelidade, que é a característica mais buscada pelas empresas atualmente, pois proporciona rentabilidade. Segundo Thrinidad (2015), citado por Tiago (2015, p. 16), ser gentil é bem mais que ser educado, respeitoso, simpático, bem-humorado ou cordial, ser gentil deveria ser um dever social, pois a gentileza provoca reação positiva em qualquer pessoa, não importa o ambiente. Um ato de gentileza marca o dia de alguém como um gesto que favorece o bem-estar:

A gentileza é tão sutil que é a primeira coisa que se percebe quando alguém adentra a porta e saúda a todos com um sorriso nos lábios e a última coisa a ser esquecida, quando esse mesmo alguém se despede, deixando impresso a cortesia personalizada desse gesto.

Barros (2018, p.27) define a gentileza como sendo:

Uma forma particular de pensar para agir em convivência. Segundo a qual a existência de qualquer pessoa - em interação real ou potencial com quem age - é fator relevante na definição dos limites que este agente se importará para evitar-lhe dano, tristeza ou incômodo.

A definição de Barros demonstra a importância do pensamento, da ação e dos limites da ação para que os impactos não causem dano, tristeza ou incômodo. Pensar e agir gentilmente é uma escolha dentro do caráter dual das pessoas. O ser humano é 
naturalmente bondoso e maldoso, gentil e grosseiro, e, assim, suas escolhas influenciam na sua evolução, conforme comenta Comparato (2016, p. 473):

A ideia de conceber o homem como um ser perpetuamente in fieri, e, portanto, eticamente ambíguo, misto de anjo e demônio, capaz, pela sua própria iniciativa, de se aperfeiçoar ou se degradar ao extremo, já havia sido afirmada por Aristóteles: "Assim como o homem é o melhor dos animais quando perfeito, ele é o pior de todos quando afastado do direito e da justiça".

Cortella, citado por Barros (2018), comenta que todos temos o compromisso de ajudar a formar pessoas e encantá-las para a gentileza, de modo que essa virtude se transforme em reciprocidade generalizada na vida de todos, vivenciando o propósito de que as pessoas façam o seu melhor para não produzir voluntariamente nas outras pessoas, e em si mesmas, dano, tristeza ou incômodo. Cortella, citado por Barros (2018, p.10), diz que "A gentileza precisa e pode ser exigida, aprendida, ensinada, praticada, protegida e partilhada; essa é uma série de ações que nós, de alguma maneira, docentes ou não, mas sempre educadoras e educadores, temos de exercer em nosso cotidiano".

\subsection{TIPOS DE GENTILEZA}

\subsubsection{PEQUENAS GENTILEZAS}

Harrison (2007) diz que as pequenas gentilezas são comportamentos tangíveis, característicos e específicos, normas de reciprocidade e tradições honradas pelo tempo e que somados criam uma cultura ética e formam a estrutura de uma organização contribuindo com a sua sustentabilidade e reduzindo sua vulnerabilidade. As pequenas gentilezas são os comportamentos e atitudes que, juntos, contribuem com os membros da organização na construção de padrões de como as pessoas irão agir. Elas permitem que as pessoas de uma organização digam a si mesmas: 'é assim que fazemos as coisas por aqui', ou, conforme o caso, 'não é assim que fazemos as coisas por aqui'. Comportamentos que criam uma cultura exclusiva e altamente 
eficiente são filtrados por meio do compromisso do líder maior da empresa para com um ambiente organizacionalmente nivelado, não-hierárquico e despretensioso.

Esses comportamentos demonstram como as "pequenas gentilezas são os alicerces que dão o tom a uma organização que oferece a conectividade às suas pessoas e uma razão de ser - o porquê de irmos ao escritório pela manhã. Esses gestos/atos pessoais, quando iniciados, podem se transformar num ciclo positivo que contribui com um ambiente mais agradável, principalmente quando a pessoa é o líder maior da empresa. Para que esse ciclo se inicie, Harrison (2007, p.68) diz que "os líderes modelam os gestos - idealmente replicáveis e escaláveis - que podem criar uma fundação mais desenvolvida para uma cultura concordante". Mesmo com os gestos modelados e replicados, as pequenas gentilezas por si só podem não ser o suficiente para construir a tão sonhada cultura ética, e, assim, uma outra alavanca pode ser utilizada pelos líderes: o emprego de grandes gentilezas.

\subsubsection{GRANDES GENTILEZAS}

Para Harrison (2007), uma pequena gentileza pode se transformar em uma grande gentileza. Uma rede de lojas que possua uma excelente recepcionista, que seja um exemplo a ser seguido no quesito gentileza, ao modelar os gestos, criar um programa formal para a função, e, assim, investindo no treinamento pessoal de outros profissionais, implementa-se o mesmo comportamento nas demais lojas, criando-se, então, uma grande gentileza. A definição de grande gentileza de Harrison (2007, p. 69) é "todo gesto que, desde o começo, envolva custos, quebre regras existentes ou exija a participação específica de outros dentro da organização".

Há outros exemplos que são classificados como grandes gentilezas que podem ser aqui mencionados: mimos oferecidos a clientes e funcionários; programa de voluntariado; bolsas de estudos oferecidas para filhos de colaboradores; programas corporativos de responsabilidade social; as fundações que, por definição, são grandes gentilezas, dentre outras possibilidades. Harrison (2007, p. 70) acrescenta que é "impossível executar mudanças de cultura somente com grandes gentilezas. Grandes gentilezas sem pequenas gentilezas que as sustentem perdem muito seu impacto". 


\subsection{GENTILEZAS EM AÇÃO}

Harrison (2007) afirma que as gentilezas oferecidas colocam valores em prática: valores do indivíduo e da organização. As gentilezas podem ser agrupadas por temas interligados:

\subsubsection{GENTILEZAS DE CONSIDERAÇÃO}

Quem já ficou muito tempo esperando para falar com alguém sabe o quanto uma falta de consideração é insultante, pois essa atitude diz que esse alguém não é importante e tem uma baixa prioridade. Ser pontual é uma gentileza que conta, porque é respeitoso com a pessoa que disponibilizou seu tempo. Além disso, as pessoas comentam com outras quando são ou não respeitadas e isso cria uma reputação para as pessoas e para as empresas. O respeito deve vir em primeiro lugar. Harrison (2007), conceitua respeito como a consideração por si próprio e para com os outros.

Consideração com a privacidade, com o espaço físico, com os pertences e com o tempo é essencial. É importante ter respeito pelos diferentes pontos de vista, filosofias, visão política, limitações e crenças, reconhecendo os valores mais intrínsecos das pessoas por meio do tratamento dispensado a elas. As gentilezas mais básicas são as que mais demonstram respeito e consideração. Um "olá" e um "até logo" são óbvios. Não cumprimentar as pessoas, mesmo quando se cruza pelo corredor ou pela calçada, é o mesmo que não as considerar como membros da sociedade. Primeiro as pessoas, depois as coisas, as estratégias etc.

\subsubsection{GENTILEZAS DE RECONHECIMENTO}

Muitas empresas investem muitos recursos e até fazem um bom trabalho com programas de reconhecimento, porém muitas organizações perderam a imediação e a intimidade dos gestos espontâneos de reconhecimento. As pequenas gentilezas são autênticas, de baixo custo, espontâneas e não precisam de autorização superior nem planejamento prévio, ou seja, podem ser usadas com frequência para reconhecer as pessoas. Nelson, citado por Harrison (2007), diz que o reconhecimento deve ser: 
imediato, pois tempo é importante e não se deve retardar elogios. Precisam ser sinceros e devem ser feitos por quem é verdadeiramente reconhecedor assim como é necessário fornecer dados detalhes da realização, precisam ser feitos pessoalmente ou deve-se deixar recados escritos à mão, não se deve misturar com o positivismo com criticismo e devem ser proativos, devem ser esperados em razão de um desempenho perfeito.

Um reconhecimento pode ser feito por meio de um simples "obrigado" verbalizado, uma carta de agradecimento, um bilhete inesperado elogiando ou agradecendo. Essas ações fazem diferença na vida diária de qualquer profissional, e, portanto, são recomendadas. Além do bilhete e da carta, o elogio pode seguir por outros meios e ter até outros destinatários: a família do colaborador pode receber uma cópia de uma avaliação positiva ou mesmo o elogio pode ir anexo ao demonstrativo de pagamento, agradecendo a contribuição do colaborador. Os elogios e reconhecimentos devem ser sempre priorizados e Harrison (2007, p. 94) dá a dica: "Aqui está a gentileza: se você vir algo que não Ihe agrada, anote e guarde o feedback para uma outra ocasião", quando isso não é feito, há grandes chances de ser lembrado mais pelas críticas feitas do que pelos elogios, causando estresse e até medo nas pessoas com quem se convive.

\subsubsection{GENTILEZAS DE ESCUTAR}

Todos querem e gostam de ser ouvidos, mais que isso, o ser humano se agrada com os benefícios de ser escutado com qualidade. Harrison (2007, p.103) afirma que "depois da sobrevivência física, a maior necessidade dos seres humanos é a sobrevivência psicológica - ser compreendido, ser confirmado, ser validado e ser estimado". Escutar é mais do que se juntar e compreender informações; escutar perceptivelmente é um sinal de respeito. Harrison (2007, p.103) garante que "qualquer um consegue melhorar seu nível de desempenho pensando estrategicamente sobre escutar e praticar habilidades eficientes em escutar". Assim,

Criticar as pessoas ao intrometer-se em suas situações; fazer caretas ou emitir sons de reprovação; 'resolver' seus problemas com uma rápida 
sugestão; interrogá-las para fazer com que cheguem a uma conclusão predeterminada; tentar animá-las, dizendo que as coisas não são tão ruins (HARRISON, 2007, p. 105).

Considerando tal contexto, é possível afirmar que muitas das gentilezas em relação ao ato de escutar parecem óbvias, mas sempre contribuem no sentido de que se está sendo escutado verdadeiramente, dentre elas: resistir à tentação de interromper o interlocutor, valorizar o silêncio, procurar compreender antes de tentar ser compreendido e apenas dar conselhos quando são solicitados. Harrison (2007, p.105) exemplifica faltas de gentileza de escutar, como mencionado antes, e, dessa forma, recomenda que é interessante evitar fazer caretas ou emitir certos sons de reprovação durante a comunicação. O ideal é chegar a um acordo, pois a crítica construtiva deve ser incentivada.

\subsubsection{GENTILEZAS DE DEMISSÃO}

Bob Hecht, citado por Harrison (2007, p. 133), diz que "as três maiores tragédias do mundo de uma pessoa são a morte, o divórcio, e a perda do emprego". Harrison (2007), salienta que, para muitas pessoas, o sentimento de uma demissão se assemelha ao da morte, pois as pessoas se identificam intimamente com o que fazem para ganhar a vida. Quando pessoas perdem seus empregos acabam perdendo, também, elementos essenciais de suas identidades, como renda salarial e renda física. Infelizmente, alguns chegam a entrar em depressão, ameaçando até mesmo sua razão de ser, apresentando comportamentos autodestrutivos, violentos e até suicidas. Tornar mais fácil e humano esse processo é fazer o uso de pequenas e grandes gentilezas na demissão, que é o momento em que elas são mais necessárias. Harrison (2007, p. 134) é muito assertivo ao dizer:

Muitas empresas fazem tudo o que é possível para evitar dispensar colaboradores. Algumas vezes, porém, a realidade econômica torna isso impossível. Quando a dispensa de colaboradores é eminente, as pequenas gentilezas podem fazer toda a diferença. Um simples compromisso gerencial com as pequenas gentilezas durante $e$ 
imediatamente após uma dispensa em nada interfere com as necessidades econômicas que a forçaram. Pequenas gentilezas colocadas em jogo durante e depois dessa que é a mais difícil das tarefas do gerenciamento - 0 ato de desligar um colaborador - sinalizarão a sensibilidade e o cuidado de um líder, e um compromisso para com todos que estejam observando. E aqui vai um ponto crítico: todos - e eu digo 'todos' - estão observando durante e depois de um corte de colaboradores. Esse não é o momento para uma miopia administrativa.

Um bom exemplo é o da Agilent, subsidiária da Hewlett-Packard, que, em 2001, apesar de ter uma cultura de emprego permanente, foi forçada a eliminar 4.000 funcionários, o que correspondeu a 9\% da empresa, decorrente de um declínio econômico que a atingiu. O presidente da companhia apresentou três regras básicas: $\left.1^{\circ}\right)$ Os colaboradores deveriam ser notificados apenas por seus gerentes diretos, $2^{\circ}$ ) Os gerentes tinham de ser claros e honestos; $3^{\circ}$ ) As decisões dos cortes deveriam ser baseadas em critérios publicados. Os funcionários da Agilent tomaram conhecimento do prejuízo trimestral de $\mathrm{R} \$ 219$ milhões diretamente pelo CEO da empresa, por meio do sistema de som corporativo, para que não soubessem dos cortes pela mídia. Ele apresentou o péssimo estado econômico do negócio, reconheceu os sacrifícios que os colaboradores já haviam realizado e foi claro ao detalhar o número de pessoas que poderiam perder seus empregos, a origem dos números e como seria o doloroso processo.

Essa gentileza de fazer o anúncio diretamente e pessoalmente fez com que o processo começasse com o pé direito. A Agilent conduziu o processo da forma mais transparente possível. Os critérios nos quais as decisões de escolha se baseavam foram publicados na intranet corporativa, para acesso de todos colaboradores. A Agilent buscou o máximo de justiça e o mínimo de ambiguidade no processo, disponibilizando treinamento para mais de 3.000 gerentes, com duração de 1 dia inteiro. Nesse período eles interpretaram papéis e praticaram as maneiras corretas e incorretas de demitir pessoas, no dia imediatamente anterior ao evento. Harrison 
(2007, p. 138) diz que "eles foram ensinados a como responder não-reativamente e com empatia às expressões emocionais de um colaborador, que podem ser intensas".

A Agilent considerou lamentável a quantidade de demissões, mas não um motivo para se envergonhar. Devido ao contexto delicado, foi a alternativa que encontraram. Muitos dos colaboradores dispensados escreveram para o presidente da companhia dizendo que estavam satisfeitos, não com o resultado do processo, mas com a justiça e a gentileza com que foi conduzido. Um bom planejamento prévio é fundamental para uma demissão ser cuidadosamente coreografada, evitando deslizes. Não é o momento para um gerente ser espontâneo. Se existir, por exemplo, 50 coisas que podem dar errado na demissão e o gestor conseguiu pensar em 49 delas, antecipando formas positivas de reconduzir a demissão, ele foi um gênio. Harrison (2007, p. 145) resume as exigências mínimas de gentileza na demissão de colaboradores em cinco valores:

1) Um processo de seleção justo e preferencialmente transparente. Isso significa padrões objetivos e facilmente compreensíveis.

$\left.2^{\circ}\right)$ Uma notificação dada pessoalmente em uma reunião cordial e com a presença do supervisor imediato do colaborador demitido.

3ํ) Sensibilidade com a logística do processo de notificação.

$4^{\circ}$ ) Sensibilidade com relação à carta de referência. O colaborador desligado deverá saber exatamente o que a empresa irá dizer aos potenciais empregadores. Isso deverá ser feito por escrito, de maneira que ambas as partes fiquem satisfeitas.

5º) Acessibilidade da administração aos colegas mantidos.

Uma perda de emprego, apesar de ruim e difícil, sempre acaba sendo aceita pelas pessoas, entretanto, há que se mencionar que o inaceitável e dificilmente perdoado é um processo de redução de pessoal não ser conduzido com foco na dignidade humana. Todos temos a obrigação de buscar minimizar os riscos de alguma coisa ser 
considerada uma afronta à dignidade individual. Em um ambiente no qual a gentileza impera, os colaboradores desligados tenderão a tocar sua vida em diante com mais facilidade, ao contrário de um desligamento conduzido com falta de dignidade, visto que traumatizará a pessoa pelo resto da vida, mesmo após ter se conformado com o desligamento.

\subsection{A GENTILEZA NA LIDERANÇA}

Melo (2017), define liderança como sendo a influência intencional que é evidenciada por uma pessoa sobre outras, atraindo o compromisso dos seguidores de forma voluntária, levando-os a lutarem por aspirações compartilhadas. Liderar é dar uma boa causa pela qual as pessoas queiram lutar, em qualquer área da vida, contribuindo e criando maneiras de as pessoas fazerem coisas extraordinárias acontecer. Ao fazêlo, o líder conseguirá que, alegremente, as pessoas realizem o que normalmente sofreriam para fazer, ou seja, trabalhar em nível de superação. Para atrair seguidores voluntariamente, de modo que realizem alegremente uma atividade, por mais penosa que seja, o líder pode se valer das gentilezas de humildade executiva descritas por Harrison (2007). Harrison (2007, p. 112) fala da humildade na liderança para combater a arrogância executiva nas empresas:

Muitos líderes deixam sua autoridade subir às suas cabeças. Ela produz um sentido de direito de posse. Tudo o que esse comportamento faz é distanciar esses executivos de seus colegas e clientes e, no final de tudo, de seus negócios. Por mais que possa inflar seus egos, a arrogância esvazia outros em volta deles.

Harrison (2007), comenta que muitos executivos confundem ter privilégios com arrogância. É perfeitamente possível ter os privilégios inerentes ao cargo de executivo mantendo boas relações de cordialidade, educação, respeito, empatia e compaixão pelos gerentes e colaboradores comuns. Há executivos que desdenham todo tipo de arrogância executiva e nem por isso são líderes menos eficientes. A arrogância é contraproducente nas organizações. 


\subsubsection{GENTILEZAS AO TELEFONE}

Há executivos que atendem suas próprias ligações, por mais que eventualmente haja uma ligação por engano ou um vendedor insistente, nada supera o compromisso de reduzir a arrogância. Harrison (2007, p. 113) afirma que, ao atender suas próprias ligações, o executivo passa a seguinte mensagem:

Considero a sua ligação muito importante e não quero fazer com que perca seu tempo tratando com um intermediário. Porém, eu quero que você respeite o meu tempo. Isso significa identificar-se imediatamente, ir direto ao assunto e, se eu disser que não estou interessado, respeitar minha decisão.

Isso está diretamente relacionado à reputação, pois as pessoas comentam e o assunto se espalha. É um gesto simples que reforça uma cultura aberta, confiante e apropriada.

\subsubsection{ANFITRIÕES E CONVIDADOS}

Considerando que o ambiente de trabalho é um reservatório de interações sociais, Harrison (2007) destaca que em qualquer interação social ou você opera como anfitrião ou como convidado e há expectativas para cada papel. O gestor que não compreende isso falha grandemente na forma de interagir com as pessoas. Os conflitos interpessoais nas empresas, em muitas das vezes, podem estar relacionados ao desrespeito às obrigações de anfitrião/convidado. Quando um gerente convoca uma reunião, ele age como anfitrião e as pessoas que participam da reunião são seus convidados. Isso vale mesmo para aquelas reuniões cujo comparecimento é obrigatório.

O anfitrião, em qualquer lugar que seja, mesmo no trabalho, tem de fazer com que os convidados se sintam bem recebidos. Os convidados igualmente têm suas responsabilidades, como responder imediatamente ao convite, ser pontual, vestir-se adequadamente e participar ativamente. Harrison (2007), orienta, ainda, a se adotar 
o princípio de que, ao se convocar uma reunião, seja o primeiro a chegar e o último a levantar para sair, pois é um sinal sutil de humildade e respeito, uma gentileza tão poderosa quanto um aperto de mão e isso é demonstrar que o anfitrião não se considera melhor nem superior aos convidados, principalmente quando são seus colaboradores.

\subsection{A GENTILEZA NA CULTURA CORPORATIVA}

Quando uma pessoa é apaixonada pelo seu trabalho, ela se torna parte dele e viceversa. Para muitos colaboradores, a mais alta expressão do seu compromisso é fazer a diferença por meio de um bom trabalho e Harrison (2007, p. 147) diz que "as gentilezas estimulam a transformação das formas comuns e diárias em excelentes e raras" e "são o caminho para que indivíduos e organizações se expressem e até mesmo sustentem o próprio significado da sua razão de ser". As gentilezas existem em diversos tamanhos, das pequenas até as maiores. Harrison (2007) comenta que as pequenas gentilezas nas organizações, quando começam a se generalizar, passam a fazer parte da empresa, tornando-se grandes gentilezas institucionalizadas, sendo praticadas não apenas pelas pessoas, mas pela empresa.

As gentilezas estão, fundamentalmente, relacionadas com o compromisso de um indivíduo em fazer a coisa certa. Por causa dessa instrução básica, não consigo conceber um programa de RSC eficiente e autêntico na ausência de uma cultura de pequenas gentilezas (HARRISON, 2007, p. 158).

Muitas ideias começam com pequenas gentilezas e acabam evoluindo para algo bem maior, como os programas que incentivam as pessoas a agirem com gentilezas. Também há grandes gentilezas que evoluem e ultrapassam as fronteiras da empresa, como a responsabilidade social corporativa - RSC. Apesar de as gentilezas andarem de mãos dadas com a RSC, essas duas funcionam em níveis diferentes. As gentilezas brotam a partir dos valores de uma pessoa, já a RSC aparece a partir dos valores de uma empresa. Assim como pequenas gentilezas podem evoluir para grandes, os líderes podem realizar gestos que se tornem grandes feitos. 


\subsection{A MUNDIALIZAÇÃO HUMANISTA}

Comparato (2016, p. 434), ao analisar os números fornecidos pela ONU Organização das Nações Unidas - no Relatório de Desenvolvimento Humano de 2004, sobre a explosão demográfica, a fome, a sustentabilidade ambiental e a desigualdade econômico-social no mundo, comenta:

A questão da sobrevivência da nossa espécie põe-se hoje, portanto, de forma iniludível, a todos os homens de consciência e de responsabilidade. A humanidade somente terá condições de enfrentar esse formidável desafio se souber encontrar uma forma de união na qual todos os povos do mundo possam viver livres e iguais em dignidade e direitos.

Comparato (2016, p.435) aponta, ainda, que os dramas vividos atualmente têm origem histórica:

Até o advento da era moderna, no Ocidente, sempre se concebeu a vida social como devendo fundar-se no altruísmo e na supremacia do bem comum sobre o interesse privado. Já no início do século XVI, porém, a pregação maquiavélica de uma 'política de resultados', a ser conduzida com base em quaisquer meios, abriu a primeira fratura ética entre a vida privada e a vida pública. O príncipe, em sua condição de herói situado acima do comum dos mortais, não se submetia à ética geral, vigente para os seus súditos. Concomitantemente, a insistência da teologia protestante na inutilidade das 'boas obras' para a salvação eterna, e a retomada de uma certa concepção veterotestamentária de que o êxito nos negócios deste mundo seria um sinal premonitório de que o fiel está incluído no rol dos eleitos do Senhor, serviram incontestavelmente de justificativa moral para um estilo de vida individualista, em que predominou a geral despreocupação com as desigualdades sociais. 
Comparato (2016, p. 437) comenta que, desde a Revolução Industrial, as desigualdades aumentaram cada vez mais, com as riquezas produzidas ficando cada vez mais concentradas em um grupo menor de pessoas e afirma que "um outro mundo é possível: a mundialização humanista". Comparato (2016, p. 438) acrescenta que:

Em direta contradição com o espírito imperialista e totalitário, dominante em seu tempo, Mahatma Gandhi, ao reascender o sagrado princípio do altruísmo, fundamento ético das grandes religiões, no Oriente e no Ocidente, pregou incansavelmente, inclusive com a própria morte, o respeito integral à Vida, em todas as suas modalidades. Graças à influência fecunda e regeneradora desses grandes valores éticos, foi sendo construído, andar por andar, o grandioso edifício do sistema universal dos direitos humanos.

Comparato (2016, p. 438) esclarece ainda:

Enfatize-se, porém, que a mundialização humanista não significa, de forma alguma, desprezo pelo saber tecnológico, ou o não reconhecimento do seu papel insubstituível no processo evolutivo da espécie humana. Técnica e ética complementam-se, necessariamente, para impulsionar os povos e as civilizações a se unirem. A tecnologia, divorciada da ética, conduz à inevitável fratura da humanidade. A ética, ignorante do saber tecnológico, é ineficiente e vazia. $\mathrm{O}$ grande projeto de humanização do mundo exige que a ciência e a técnica sejam finalmente reconhecidas como patrimônio da humanidade, insuscetíveis, portanto, de qualquer tipo de apropriação, privada ou estatal.

Esse projeto de mundo é descrito por Comparato (2016) como sendo mais livre, justo e solidário, fundamentado na ética. 


\subsection{GENTILEZA COMO FONTE DE BEM-ESTAR AO PRATICANTE}

Ferreira (2018), diz que é possível e essencial a qualquer pessoa diminuir o peso do cotidiano. Apesar da vida ser muito difícil, a leveza contribui muito para que as pessoas passem com mais facilidade pelas dificuldades. Ferreira $(2018$, p. 7$)$ comenta que ser leve é "viver com menos peso na alma, menos tralhas na bagagem, menos aspereza nas palavras e nos gestos, menos azedume, menos pressa e consumismo". O Antropólogo Oliver Scott Curry et al (2018), professor do Instituto de Antropologia Cognitiva e Evolucionária da Universidade de Oxford, no Reino Unido, pesquisou os efeitos da prática de gentilezas no bem-estar do ator. Os 27 estudos realizados contaram com 4.045 participantes do Canadá, Estados Unidos, Europa, África do Sul, Coréia e Vanuatu.

Durante o estudo, praticaram atos de bondade, gentileza e gastos pró-sociais com o objetivo de testar a hipótese de que a gentileza causa bem-estar. Os resultados forneceram uma série de explicações para o desenvolvimento humano social, cooperativo e altruísta. Curry et al (2018), com sua pesquisa, concluiu que as pessoas ficam felizes em ajudar a família, os amigos, os membros da comunidade, seus cônjuges e até mesmo pessoas estranhas. $O$ efeito pode ser maior para determinados tipos de ajudantes e ao ajudar determinados tipos de pessoas. A pesquisa auxilia na compreensão das causas e consequências da gentileza, além de auxiliar profissionais a maximizarem a eficácia de gentilezas.

\subsection{A NEUROBIOLOGIA DA GENTILEZA}

O neurocientista O'Connor (2018) diz que a gentileza é uma parte fundamental da condição humana e preenche as divisões da cultura, religião, política, gênero e classe social. O surgimento da neurociência, estudo científico do sistema nervoso, trouxe novas maneiras de responder perguntas como o quanto a gentileza é importante. O'Connor (2018) explica que:

A descoberta de neurônios-espelho, um aglomerado de neurônios no cérebro que nos ajuda a nos conectar emocionalmente com outras 
pessoas, responde simpaticamente aos outros e nos permite antecipar outras intenções que hoje se acredita serem a base da empatia humana.

O'Connor (2018) afirma que a gentileza é o motor para o crescimento pessoal:

Cada pessoa é um espelho de seu ambiente que, por sua vez, é espelhado por seu próprio comportamento. Isso é subjacente ao poderoso fenômeno do contágio social - que informações, ideias e comportamentos, incluindo gentileza, podem se espalhar através de redes de pessoas da mesma maneira que as doenças infecciosas. Por essa razão, dar e receber gentileza pode ter um efeito contagioso. A pesquisa também mostra que a aprendizagem ideal ocorre em um ambiente que é criativo, inclusivo, recompensador e reforçado por limites firmes e saudáveis, em um ambiente que é amável. Mesmo aqueles em profundo sofrimento devido à prisão, vício, preocupações financeiras e alta ansiedade também se beneficiam enormemente de um ambiente criativo, inclusivo e delimitado. O que fazer quando nos deparamos com indelicadeza? Comportamentos, incluindo ansiedade, raiva e grosseria também podem se espalhar através de redes de pessoas da mesma forma que as doenças infecciosas. O antídoto para não se infectar com esses estados miseráveis é estar ciente de que toda ação deve ser conscientemente escolhida, e não uma resposta emocional.

O'Connor (2018) explica por que a gentileza é tão importante:

Essa questão pode ser respondida no contexto em que cada ser humano é único porque cada um de nós representa um cérebro singularmente complexo, tão complexo que, em toda a história, nenhum cérebro humano pode ser idêntico. Isso ocorre porque a combinação única de cerca de 100 trilhões de minúsculas conexões cerebrais (sinapses) que crescem e mudam ao longo da vida é um trabalho contínuo em andamento desde a concepção até a morte. Desta forma, cada um de nós 'evolui' como indivíduos verdadeiros à medida que cada um de nós 
faz a nossa jornada pela vida. A gentileza é a luz verde para continuar; se você não está aberto a dar e receber gentileza, então você pode não estar crescendo do mesmo modo, a humanidade só evoluirá abrindo espaço para que cada indivíduo expresse sua evolução intelectual e espiritual ao máximo, desta forma, a evolução da raça humana tem tudo a ver com estar aberto a dar e receber gentileza.

\subsection{FORMAS DE ESTIMULAR A PRÁTICA E A DISSEMINAÇÃO DA GENTILEZA}

\subsubsection{ETIQUETA EMPRESARIAL}

Araújo (2004, p. 1) define etiqueta como "um conjunto de pressupostos, consagrados pelos vários grupos sociais, que buscam a convivência harmônica e o entendimento entre as pessoas. É o código do bem viver." Araújo (2004), ressalta que o ser humano precisa se relacionar frequentemente com outras pessoas, porém, dependendo do tipo de relações que que serão construídas, pode se instalar a felicidade ou a frustração, mas inevitavelmente as outras pessoas estarão envolvidas nesse processo. Para que um relacionamento seja de ganha-ganha, ou seja, para que as nossas expectativas resultem no bem-estar do outro, as autoestimas de todas as pessoas envolvidas devem ser preservadas.

Isso deve ser buscado constantemente para que as relações se mantenham harmônicas. As expectativas podem ser diferentes dependendo do local, do contexto e do grupo de pessoas em que se está inserido. Os padrões de comportamento e de relacionamento mudam quando se está em casa para quando se está no local de trabalho. É como se representássemos um papel quando estamos em nossa atividade profissional e deixássemos de lado nossa verdadeira identidade para retomá-la somente quando retornamos ao lar no final do dia. Araújo (2004, p. 2) acrescenta:

Quando optamos por escolher um código de comportamento que respeita o nosso interlocutor como pessoa, como individualidade singular e única, temos como consequência uma vida mais saudável, 
honesta e agradável para nós mesmos, para nossos colegas de trabalho e para os demais, acrescentando muito à nossa eficácia como homens e mulheres de negócios. Nenhum ser humano possui tudo de que precisa para se bastar. Todos nós necessitamos de coisas que os outros tem para oferecer, assim como possuímos talentos de grande valor, que podemos compartilhar.

Araújo (2004), discorre em seu livro "Etiqueta Empresarial - Ser Bem Educado é", sobre como padrões de comportamentos em diversas situações do cotidiano resultam na prática de boas maneiras ao se relacionar em reuniões, corredores e situações inesperadas. É essencial sempre saber escolher o comportamento adequado para cada ocasião. As relações humanas são muito importantes para todos. Araújo (2004), diz que pesquisas da Universidade de Harvard indicam que $15 \%$ do sucesso profissional se dá em razão da capacidade técnica e que $85 \%$ se deve às competências comportamentais de relacionamentos interpessoais. Araújo (2004, p. 3) esclarece:

Quem conhece e aplica as boas maneiras e a cortesia como ferramentas em seus relacionamentos cotidianos aprende a reconhecer e a demonstrar a importância das outras pessoas, aceitando-as como são. Sabe que não deve querer modificar o outro e que deve, sim, buscar a sua própria melhoria num processo contínuo. Atende assim plenamente ao desejo universal humano, que é o de se sentir importante, reconhecido, valorizado e aceito. Mas de nada adianta ser cortês e gentil da boca pra fora. Assim só se consegue a hipocrisia. O respeito ao próximo se manifesta através de atitudes sinceras e verdadeiras, alicerçadas em certas posturas: convença-se de que as outras pessoas são realmente importantes; volte-se para as necessidades e para os desejos do outro; busque uma relação nivelada, sem postura de altivez.

Se relacionar com outras pessoas é seguir o princípio do espelho, no qual as atitudes do outro é reflexo do nosso comportamento. Portanto, devemos adotar atitudes e ações que desejamos receber das outras pessoas. 


\subsubsection{GENTILEZA NO TRABALHO}

Tiago (2015) diz que comportamento é condicionamento, de modo que é possível criar um comportamento pautado na cordialidade, no respeito, na solidariedade às demais pessoas e na gentileza. Segundo Thrinidad (2015), citado por Tiago (2015, p. 17), "aprender a ser gentil no trabalho, além de ser estratégico, ajuda a formar aliados num ambiente fomentado pela concorrência, pela pressa e pelo estresse". Tiago (2015), comenta que o ser humano é capaz de gerar sentimentos positivos pelas outras pessoas e tem a habilidade de colocá-los em prática. Se colocar no lugar do outro torna as coisas mais fáceis, por isso Tiago $(2015$, p. 23$)$ salienta que "todos nós temos que conhecer a definição da palavra empatia e multiplicá-la". O hábito de nos relacionarmos, constantemente, com colegas de trabalho, amigos ou familiares, acaba fazendo com que deixemos de ser respeitosos e cordiais e isso é um erro.

Tiago (2015, p. 24) ressalta que "a mais intolerante das criaturas acaba sendo vencida pelo cansaço por aquela que se mostra determinada, segura e com bastante leveza de espírito". Por isso é tão importante que sejamos resilientes para permanecer no propósito da gentileza, principalmente no ambiente de trabalho, que é onde passamos a maior parte de nossas vidas. Tiago $(2015$, p. 25$)$ afirma que "todos nós somos inteligentes e capazes de desenvolver várias habilidades, principalmente a humildade e a gentileza". Apesar de ser complicado no início, vale a pena, por conta da gratificação de se ter comprovado por si só que é possível realizar suas atividades e ao mesmo tempo fazer bem para si mesmo e para as outras pessoas e ainda contribuir com o crescimento de todos. Tiago (2015, p. 26) acrescenta:

Vamos pregar a paz dentro das corporações e evitar a raiva. É muito melhor compartilhar de momentos agradáveis do que se estressar e contribuir para péssimas horas de relações interpessoais. O processo de desenvolvimento harmônico deve começar dentro de nós mesmos. Não devemos esperar uma atitude alheia como se os outros que tivessem que tomar a partida sempre. Dê o pontapé inicial e comece uma campanha de boa educação e afabilidade. Vamos fazer de tudo para criar amizades e relacionamentos saudáveis no setor em que 
trabalhamos, perguntar ao colega como foi seu dia, se dormiu bem, agradecer, desejar bom trabalho e dar os parabéns por algo realizado com esmero e dedicação! Agradecer e pedir algo com o bondoso "por favor" também enobrece e dignifica pequenos gestos. Entre outras coisas que podem ser ditas, podemos levantar os ânimos das pessoas, descontrair e saber impor limites sem abusar da confiança.

Merecer a gentileza é facilitar a convivência sem extrapolar o bom senso e ferir a intimidade não sendo uma pessoa inconveniente, indiscreta e fofoqueira, principalmente no local de trabalho. Muitas pessoas não conseguem desvincular o lado pessoal do profissional, mas Tiago $(2015$, p. 30) aponta que é possível não as misturar reconhecendo a humanidade e amizade nas pessoas:

Como fazer então para não as misturar? A resposta está dentro de cada um e é intransferível. Pode ser complexa ou bastante simples: com a construção do altruísmo e a (trans) formação de um bom caráter. A gente sabe quando as pessoas têm essas virtudes e qualidades. É fácil ver que existem seres humanos dignos quando demonstram carinho e compaixão pela dor dos outros; apesar da empatia ser um mérito de poucos, deveria ser trabalhada nas corporações, pois é uma diretriz para a satisfação pessoal (...). Às vezes o problema é tão grave que não conseguimos deixá-lo do lado de fora. Aonde formos, ele (o problema) estará lá (...). Basta não se perturbar, pois levar os problemas conosco é normal e natural. Ninguém está imune a intempéries e dificuldades. Portanto, essa história é bastante relativa. Sem essa! Todo mundo tem o direito de chorar e se sentir frustrado durante o expediente! Todos podem se ausentar um tempo para respirar e tomar uma água. Nós que fazemos nosso tempo e sabemos quando é hora de arejar a cabeça. Cabe ao bom líder saber conduzir com discernimento a situação e não produzir um sentimento de culpa em sua equipe, deixando o colaborador à vontade para se refazer e se sentir protegido pela empresa. Afinal de 
contas, ninguém produz sem estar num estado de espírito harmônico e tranquilo.

As pessoas têm sentimentos e não são máquinas, de modo que a produção de cada colaborador é movida pela racionalidade e capacidade de gerir emocionalmente. Tiago (2015, p. 34) salienta que "todos querem carinho e almejam se sentir queridos". A solidariedade abre portas para a amizade e a humanização movimenta uma equipe de forma favorável com resultados que fazem um líder ser lembrado como um gestor que mereceu a posição que ocupa.

\subsubsection{A GENTILEZA É CONTAGIOSA}

Taylor (2018) diz que da mesma forma que um mau comportamento tende a se espalhar, os bons comportamentos também se alastram, de modo que a gentileza passa a ser contagiante. Taylor (2018), destaca a pesquisa realizada pelo psicólogo Jamil Zaki da Universidade de Stanford (EUA) sobre a Conformidade Positiva, que demonstra como fazer da gentileza um princípio fundamental da empresa. Nessa pesquisa, "participantes que acreditavam que os outros eram generosos se tornaram mais generosos", isso sugere que "a gentileza é contagiosa e pode cascatear entre as pessoas, assumindo novas formas ao longo do caminho". Para Taylor (2018), uma das formas de se alcançar os objetivos corporativos é, em grande parte, uma questão de políticas e procedimentos, inclusive tendo a gentileza como diretriz.

A maneira de desencadear a gentileza em uma organização é tratá-la como algo contagiante e criar condições sob as quais todos possam capturá-la. Não há um manual que descreva como construir uma cultura de conexão e compaixão entre as pessoas, e, assim, para se influenciar o comportamento de milhares de pessoas em uma organização, deve-se convencer os funcionários de todos os escalões a se unirem em um movimento de base que trate a gentileza como algo contagiante, criando uma cadeia progressiva de ações gentis. Taylor (2018), discorre que não há nenhum processo científico, isto é, nenhum algoritmo que inspira os funcionários a fazerem coisas extraordinárias. 
A única maneira de se conseguir isso é educando as pessoas, as estimulando, as incitando e dando permissão para que elas aproveitem as oportunidades de serem gentis. Além disso, segundo Taylor (2018), quando os funcionários estão motivados por um orgulho genuíno pelo que fazem, passam a demonstrar gentileza pelos clientes, ou seja, o orgulho pela marca da empresa que se trabalha é mais importante do que se pensa e proporciona uma experiência extraordinária no atendimento aos clientes da empresa. Não se pode ordenar que os funcionários sejam gentis, mas é possível desencadear uma cadeia de contágio de gentileza dentro da empresa.

\subsubsection{GIFTWORKS}

Brandão (2017) afirma que, quando as empresas compreendem que precisam despertar o pleno potencial das pessoas, criam um diferencial no mercado, e, para isso, é preciso inovar, pensar fora da caixa. Angelou, citado por Brandão (2017), diz que "as pessoas vão esquecer o que você disse e o que você fez, mas jamais esquecerão como você as fez sentir". Os giftworks auxiliam a manter as pessoas engajadas, com brilho nos olhos e sorriso estampado no rosto por meio de um mimo customizado ou um presente que tem uma importância especial para quem o recebe. Pode parecer utópico em um primeiro momento, mas Brandão (2017) afirma que as empresas que praticam giftwork ganham vantagem competitiva, apresentando rentabilidade de $11,1 \%$, mesmo em tempos de crise, enquanto as empresas sem o conceito de giftworks geraram retorno de apenas 3,8\% (Russel Investiment Group Estudo 1998-2010 - EUA). Brandão (2017) afirma que:

A performance das empresas com alto nível de confiança conta com o aumento de: produtividade, procura e nível de funcionários, qualidade do produto, inovação, capacidade de assumir riscos, colaboração e satisfação do cliente. E a diminuição de Turnover, resistência à mudança, custos relativos à saúde e número de acidentes de trabalho.

Brandão (2017) detalha que giftwork é: 
Gerar gentileza a partir de um mimo para o seu liderado com baixo custo e significado para quem está recebendo. Existe um ciclo para o giftwork acontecer, com as seguintes etapas: $1^{\circ}$ - Perceber (giftwork do funcionário); $2^{\circ}$ - Selecionar (uma oportunidade para o funcionário); $3^{\circ}$ Elaborar (a prática do giftwork); 4ํ - Apresentar (a prática com o espírito giftwork). O mais legal dessa cultura é que com o tempo todas as pessoas ficam pensando em como poderiam tornar o dia do outro, ou uma situação, mais especial, e isso é possível. Imagine agora essa cultura na sua empresa, o que poderia melhorar?

Brandão (2017) exemplifica:

Na BB Mapfre, uma executiva foi chamada à sala do diretor para ser comunicada de sua promoção. Ficou muito emocionada e disse que era de uma família humilde e que era única que tinha chegado a ter carreira e por isso, queria muito que a mãe dela estivesse lá naquele momento. Anos depois, ela foi convocada para sala do diretor, mas ao chegar lá quem estava era a sua mãe com o diretor que deu a notícia de sua promoção. Seu diretor convidou a mãe da executiva, pois sabia o quanto aquilo significaria para ela. Como vê, o diretor percebeu o que era importante para a funcionária, o que tinha valor e o que iria trazer grande satisfação e gerar um sentimento de muita felicidade ao receber. $O$ máximo que esse diretor gastou foi o valor do táxi referente ao transporte da mãe à empresa. Mas o que ele gerou tem preço? Que possamos cada vez mais gerar esse ciclo virtuoso dentro de nossas organizações, já pensou o que você pode fazer para gerar esse ciclo na empresa? Já pensou que você pode gerar giftworks a partir de agora?

\subsubsection{CONSTRUINDO UMA CULTURA GENTIL}

Para Bremer (2015) existem três tipos de culturas organizacionais e que são classificadas segundo o grau de engajamento das pessoas. No mundo ocidental tem sido cada vez maior o número de pessoas desinteressadas e infelizes no trabalho, o 
que tem elevado o número de desligamentos, mostrando que os gestores precisam olhar para seus funcionários por meio das lentes da liderança gentil, o que envolve a necessidade de fazer com que as pessoas deem o melhor de si mesmas em uma cultura na qual impera a gentileza.

Os três tipos de cultura estão relacionados com os três tipos de pessoas no trabalho: os cooperadores, os não engajados e os subversivos. Os cooperadores são emocionalmente envolvidos com o trabalho, estão felizes, colaboram, abraçam as mudanças e são motivados por algo além do que apenas a performance. Pessoas assim sentem uma conexão profunda com a empresa, colegas e gerente e esse envolvimento é representado todos os dias por meio das gentilezas. Bremer (2015) menciona que:

Os cooperadores trabalham para organizações e líderes que incentivam, treinam e desenvolvem esses comportamentos gentis como a mais alta expressão de estar e de se sair bem no trabalho. Esses líderes criam organizações amáveis ou virtuosas. A maioria das pesquisas de engajamento chama essas pessoas de Engajadas. Atualmente, entre 15 e 30\% da força de trabalho ocidental está engajada ou contribuindo.

Os não engajados fazem o mínimo exigido em seu trabalho, estão mais focados nas recompensas que podem obter do que nas contribuições que podem oferecer, são mais impulsionados pela conformidade do que pela colaboração e criatividade. Essas pessoas não engajadas, segundo Bremer (2015), "trabalham para os gestores do Deficit Mindset que se concentram no controle, eficiência e desempenho, ao invés de prezarem pela gentileza e compaixão." Paradoxalmente, essas pessoas não apresentam o melhor desempenho, apesar de ter o desempenho como foco, pois raramente experimentam uma liderança gentil. Bremer (2015), acrescenta que de 50 a $60 \%$ das forças de trabalho são não engajadas, o que corresponde ao "maior número da história e não é por acaso que vemos o mercado ocidental sob o maior nível de conformidade e regulamentação de sua história". 
Os subversivos não englobam, apenas, um grupo de pessoas infelizes, eles agem no trabalho minando ou sabotando seus colegas, por simples oposição à mudança positiva. Bremer (2015), afirma que, frequentemente, os subversivos experimentaram o oposto da gentileza no trabalho, que é a crueldade, ou, ainda, a crueldade de um líder ou de um sistema indiferente e sem amor, convertido no bullying e na violência. O tipo de cultura e liderança permeia os três tipos de pessoas no trabalho: os cooperadores estão inseridos em uma cultura que tem a gentileza como norma; os não engajados estão inseridos em uma cultura em que, em algumas das vezes, é gentil e em outras é grosseira e os subversivos estão inseridos em uma cultura que tem a intimidação e a crueldade como regra. Bremer (2015), mostra que é possível construir uma cultura de gentileza por meio da liderança positiva e da investigação apreciativa. Os líderes gentis e positivos, conforme Brumer (2015), são aqueles que:

- Aproveitam o tempo para descobrir e ampliar seus pontos fortes únicos, como empresa, como equipes e como indivíduos, por meio de abordagens colaborativas de grupos inteiros, como a Investigação Apreciativa.

- Em vez de gastar tempo evitando que coisas ruins aconteçam, os Líderes Gentis passam um tempo procurando o bem em suas organizações e como ampliar o bem para crescer. Então, ao invés de tentar descobrir as causas das grosserias, eles procuram por grandes exemplos de gentileza - o oposto da grosseria - e trabalham com seu pessoal para cocriar uma Cultura de Gentileza, descobrindo e ampliando o que funciona e o que é bom.

- Tiram um tempo para envolver seu pessoal com o coração, o que significa tirá-lo de sua atividade regularmente para discutir assuntos que são profundamente importantes para eles. Líderes gentis envolvem seu pessoal na formação do futuro da organização, começando com perguntas como quem somos, com o que nos preocupamos e qual é o nosso destino junto? 
- Tratam todas as pessoas como um ser humano único, e ajudam cada pessoa a ser mais quem elas são exclusivamente no trabalho e ainda conseguem alinhar essas diferenças de talentos em torno de relacionamentos autênticos e trabalho em equipe de alta confiança. Líderes amáveis constroem e sustentam uma comunidade solidária e compassiva no centro da organização.

As metodologias tradicionais de melhoria de negócios focam em problemas e no que não está funcionando e tentam consertá-los, o que quase sempre não dá certo ou resulta na entrega de baixos resultados, pois cria-se situações de desconfiança e culpabilização, quebrando as conexões entre as pessoas que são fonte de criatividade e cooperação nas empresas. Focar no problema quebra o pensamento criativo e inovador e dificulta olhar fora da caixa. Bremer (2015), comenta que "o condutor desse comportamento é o medo, e o objetivo é controlar e, infelizmente, muitos de nossos gerentes operam a partir dessa mentalidade porque é isso que eles aprenderam". A Investigação Apreciativa busca descobrir o que as pessoas mais gostam uns nos outros como membros da equipe ou clientes, conectando pessoas a partir de conversas autênticas e envolventes em torno de histórias positivas e inspiradoras. Bremer (2015), acrescenta que:

Ouvir essas histórias, dá esperança e libera energia criativa; em primeiro lugar, descubra os pontos fortes únicos da organização, equipe ou serviço. Em seguida, vislumbre novas possibilidades construindo esse núcleo positivo e alinhando à organização em torno desses pontos fortes. Como as pessoas no "piso térreo" estão envolvidas em contribuir para o design das mudanças, elas desenvolvem um alto grau de envolvimento com o que é proposto, e você vê uma gama rica e diversificada de ideias e possibilidades emergindo.

O processo é muito interativo, e, assim, conta com participantes que entrevistam uns aos outros, identificando experiências e pontos fortes a partir de histórias positivas e significativas. Bremer (2015), detalha a construção da Investigação Apreciativa em torno de quatro conversas: 
1 - Descoberta: Quando você experimentou atos aleatórios de gentileza em nossa organização e quais são os temas sobre o que são, como ocorrem e por quê? $2^{2}$ - Sonho: O que é possível se estendermos nossos atos aleatórios de gentileza, de modo que isso se torne a experiência normal para nós, não apenas aleatória, mas como parte da experiência cotidiana como uma Cultura de Gentileza. Quais são as oportunidades? 3 - Projeto: O que decidiremos fazer para ampliar nossas forças de gentileza, incluindo quais práticas existentes iremos estender, o que vamos parar de fazer e que novas coisas faremos? 4 - Entrega: Quais serão nossas prioridades e plano de ação para implementar nossa Cultura de Gentileza?

\subsubsection{A GENTILEZA NOS PROFISSIONAIS DO FUTURO}

Como contribuir para que as futuras gerações de profissionais sejam gentis? Rodrigues (2019), mostra o bom exemplo da pedagoga Gisele Masotti, professora da Escola Municipal de Ensino Básico Benedicta Alzira de Moraes Camunhas, que recebeu o prêmio da Prefeitura de Jundiaí-SP de profissionais inovadores dentro da rede pública de ensino. O projeto se chama "Gentileza: seja gentil". Ele contou com a participação dos seus alunos de 4 anos de idade e teve-se como intuito resgatar os gestos simples de respeito entre as crianças e todos ao seu redor.

O projeto rendeu mais frutos do que se esperava, visto que transformou totalmente $o$ comportamento dos alunos em sala de aula e impactou até mesmo a vida em suas casas, na relação com os pais e familiares. O projeto foi conduzido durante todo o ano de 2018, dividido em etapas que contaram com desenhos, leituras, vídeos e rodas de conversa com a finalidade de ensinar o real significado da gentileza aos alunos. Também foram trabalhadas as emoções dos alunos, por se considerar ser parte fundamental para que a gentileza seja praticada. Masotti, citado por Rodrigues (2019), diz que:

O projeto buscou criar relações mais saudáveis, resgatar gestos simples como dizer um bom dia, um obrigado, um desculpe. Mas o que eu mais 
queria é que saísse dos muros da escola, porque a gente vê violência, intolerância e agressividade entre as pessoas. As pessoas andam com pressa, sem ouvir o outro (...). As crianças pequenas têm dificuldades de expressar e entender suas próprias emoções. É normal sentirmos raiva, mas o que fazer com aquela raiva? Também falei sobre o amor e o carinho pelo outro. O que podemos fazer para o outro se sentir feliz?

Um dos exemplos mais nítidos dos bons resultados é sobre como a turma passou a se comportar para respeitar o aluno Rafael, que possui Síndrome de Down e autismo:

Ele necessitava de um ambiente com o mínimo de ruído possível, então eu fiz uma roda e expliquei isso para eles, disse que se fizessem barulho ele choraria. E eles se sensibilizaram. Pelo resto do ano eles fizeram silêncio na sala, acolhendo o Rafael. E a criança nessa idade a gente sabe como é, fala alto, gosta de se expressar. Foi maravilhoso.

Masotti relata, ainda, que os pais dos alunos começaram a comentar que seus filhos passaram a ser mais gentis e prestativos em suas casas, a tratar melhor os coleguinhas, inclusive dividindo os brinquedos com eles e a serem mais carinhosos com os animais domésticos. Conta a pedagoga que, sem que fosse solicitado, os alunos ajudavam os menores que não alcançavam a torneira do banheiro para lavar a mão ou mesmo ajudavam o coleguinha que não sabia amarrar o cadarço. Rodrigues (2019), acrescenta que, no final do ano, alguns resultados foram apresentados na escola, sendo eles os depoimentos dos pais, os desenhos e as fotos.

Masotti, lido a partir de Rodrigues (2019), comenta que a mãe do aluno Rafael se surpreendeu. As suas percepções apontam o seguinte sobre o papel da gentileza nesse contexto: "Ela me disse que não imaginava que os colegas gostavam tanto do filho dela e até chorou emocionada ao ver o quanto as crianças estavam acolhendo o Rafael". Masotti concluiu, dessa forma, levando o relato da mãe em consideração na sua análise, que a iniciativa impactou, de forma profunda, a vida das crianças, pois elas replicaram os ensinamentos em seus diversos círculos de relacionamento, influenciando, então, outras pessoas a serem gentis. 


\subsubsection{DIA MUNDIAL DA GENTILEZA}

Segundo a Câmara de Deputados do Brasil (2015), o dia 13 de novembro é considerado o dia mundial da gentileza. A ideia surgiu numa conferência em Tóquio, realizada em 1996, que reuniu grupos que propagavam a ideia da gentileza. O movimento foi criado oficialmente em $2000 \mathrm{com}$ a intenção de inspirar pessoas a criar um mundo mais gentil. Promover ações de estímulo à gentileza nessa data é uma das formas de se propagar a gentileza.

\section{METODOLOGIA}

A pesquisa é do tipo teórico-empírica e conta com uma amostra construída por meio da rede de relacionamentos do próprio autor. O questionário foi respondido por 100 pessoas, e, após isso, a entrevista semiestruturada foi coletada pessoalmente, em 23.07.2019, com uma das profissionais de referência em gentileza que mais foi citada na resposta da questão quatro do questionário. A pesquisa foi limitada à rede de relacionamentos do autor, e, assim, as questões foram respondidas por profissionais do setor financeiro, bancário, auditoria, terceiro setor, funcionários públicos, prestação de serviços e empresários. Os dados da pesquisa são quantitativos e serão tratados estatisticamente por meio de dados e gráficos gerados pela ferramenta Survey Monkey, e, também, qualitativos, tratados por meio da transcrição do resultado da entrevista.

\section{APRESENTAÇÃO E DISCUSSÃO DOS RESULTADOS}

\subsection{QUESTIONÁRIO}

A seguir serão apresentadas e discutidas as respostas dos 100 (cem) participantes do questionário semiestruturado. Elas foram coletadas por meio da ferramenta Survey Monkey. A primeira pergunta questionou se a definição de gentileza é algo claro para o respondente, ou seja, se ele saberia dizer o que é gentileza. $94 \%$ responderam "sim", 1\% respondeu "não" e 5\% responderam "mais ou menos". A grande maioria dos respondentes estava convicta da definição de gentileza. Isso é fundamental para as 
próximas questões que serão respondidas. Apesar de os respondentes estarem convictos do conceito de gentileza, as definições trazidas por Cortella e Barros (2018) demonstram algo muito complexo, isto é, que boa parte dos respondentes pode não ter noção da profundidade, considerando que a gentileza envolva a importância do pensamento, da ação e dos limites da ação para vivenciar o propósito de que as pessoas façam o seu melhor para não produzir voluntariamente nas outras pessoas e em si mesmas, os danos, a tristeza ou o incômodo.

A segunda pergunta questionou sobre a percepção do respondente, seja como cliente ou como profissional, quanto à existência de gentileza nas empresas: $76 \%$ responderam que "existe muito pouco", $24 \%$ disseram que "existe na maioria das vezes", nenhum respondente indicou que "não existe" ou que "existe plenamente". A grande maioria dos respondentes percebe que existe muito pouca gentileza nas empresas, o que é lamentável, considerando que Harrison (2007) destaca que as gentilezas tornam a conversa sobre ética mais palpável, principalmente nas empresas. A maioria das gentilezas custa quase nada e representam mudanças que podem produzir resultados grandiosos, inclusive uma cultura corporativa que ajuda a proteger as empresas de lapsos éticos, ofensas no local de trabalho e fraudes. As gentilezas oferecidas colocam valores em prática, sejam eles do indivíduo ou pertencentes à organização.

Existir muito pouca gentileza para $76 \%$ dos respondentes indica que, na visão deles, as empresas poderiam possuir melhores valores, mais adequados às necessidades das pessoas. Há um campo imensurável de oportunidades de atuação para que clientes e funcionários percebam, sintam e recebam gentilezas. É um desperdício de oportunidades, principalmente porque Thrinidad, citado por Tiago (2015), ressalta que ser gentil no trabalho é estratégico e ajuda a formar aliados num ambiente onde há concorrência, pressa e estresse. A terceira pergunta teve como objetivo aferir a percepção do respondente sobre o grau de influência nos resultados financeiros e produtividade dos investimentos em ações e políticas para o aumento da prática de gentilezas entre os funcionários. $98 \%$ responderam que entendem que proporciona maiores resultados financeiros e produtividade, $2 \%$ responderam que não há 
influencia alguma e nenhum dos respondentes disseram que percebem resultados financeiros e produtividade em menor escala.

A grande maioria, 98\%, afirma que investimentos em ações e políticas para o aumento da prática de gentilezas entre os funcionários aumentaria resultados financeiros e a produtividade. Isso confirma o que foi comentado na questão anterior, a segunda, havendo grande desperdício de oportunidades, oportunidades estas que a gentileza poderia gerar. Curry et al (2018), Ferreira (2018), O'Connor (2018), Tiago (2015) e Taylor (2018) afirmam que a gentileza pode auxiliar no crescimento pessoal e melhorar o bem-estar, a satisfação e a felicidade das pessoas e, além disso, $98 \%$ dos respondentes afirmam que a gentileza pode ampliar os resultados financeiros e a produtividade. Não ser gentil é desprezar a felicidade e desperdiçar oportunidades, recursos e riquezas que poderiam estar sendo geradas. Por isso Tiago (2015) afirma que a gentileza é o grande trunfo do profissional que quer fazer a diferença no mercado para atrair e fidelizar clientes e melhorar resultados.

Por meio da gentileza, aumentam-se as possibilidades de se construir o mundo descrito por Comparato (2016): um mundo mais livre, justo e solidário, fundamentado na ética. As ações para a promoção da gentileza podem começar, por exemplo, com um investimento irrisório na celebração do dia mundial da gentileza, com o estímulo de ações simples que podem virar hábitos ao serem repetidas nos demais dias do ano. A quarta pergunta foi feita com intuito de levantar o nome de um profissional a ser possivelmente entrevistado, como de fato ocorreu e será detalhado no próximo item deste trabalho. Foi solicitado ao respondente o nome de um/uma profissional com quem já trabalhou que, no seu entendimento, é referência em gentileza. Dentre as pessoas mais citadas, em primeiro lugar, com $7 \%$ das indicações, foi o autor deste artigo, em segundo lugar, com $6 \%$ das indicações, foi citada Renata Geiser Mantarro, que foi entrevistada pelo autor cuja transcrição da entrevista está no item 4.2. deste artigo.

A quinta e última pergunta visou aferir uma autoavaliação do respondente sobre o quanto ele se considera uma pessoa gentil. $47 \%$ responderam que "se consideram um pouco gentil", $45 \%$ responderam que "consideram que possuem uma gentileza 
acima da média", $6 \%$ responderam que "se consideram referência em gentileza" e $2 \%$ responderam que "não se consideram uma pessoa gentil". A forma como $47 \%$ dos respondentes se veem é a de que são um pouco gentis, ou seja, poderiam ser mais, somados aos $2 \%$ dos que assumidamente não são gentis, são quase a metade dos respondentes. Por qual motivo não são mais gentis? Considerando que $94 \%$ sabem o que é gentileza, $76 \%$ dizem que existe pouca gentileza nas empresas, Curry et al (2018) afirma que gentileza traz felicidade e $98 \%$ afirmam que a gentileza aumenta resultados e produtividade: não ser gentil é deixar de aproveitar o potencial que se tem nas empresas e até na própria vida, potencial de produtividade, de resultados, de qualidade de vida e de felicidade. Ser gentil é um excelente negócio!

O resultado da última pergunta reforça a colocação de Comparato (2016) de que pensar e agir gentilmente é uma escolha dentro do caráter dual das pessoas (gentis/grosseiras) e suas escolhas influenciam na sua evolução. É preciso querer, escolher e decidir ser gentil, diariamente. Tiago (2015), afirma que comportamento é condicionamento, de modo que é possível criar um comportamento mais gentil, cordial, respeitoso e solidário. As palavras de Cortella, citado por Barros (2018), de que todos temos o compromisso de ajudar a formar pessoas e encantá-las para a gentileza, de modo que essa virtude se transforme em reciprocidade generalizada na vida de todos, nos mostra que ser gentil é uma opção que deve ser feita todo dia, por cada um de nós. Isso exige persistência, dedicação e esforço, o que, certamente, proporciona excelentes resultados.

\subsection{ENTREVISTA}

A análise das respostas da quarta pergunta do questionário mostrou que uma parcela maior dos respondentes considera Renata Geiser Mantarro uma profissional que é referência em gentileza. A seguir será apresentada a transcrição da entrevista, realizada em 23.07.2019, que será comentada na sequência. Renata é diretora do $\mathrm{BBI}$ - Banco Bradesco Investimentos e foi superintendente executiva da auditoria interna do Banco Bradesco nas áreas de tecnologia da informação e de negócios. Estudou MBA em Gestão Estratégica de Negócios na Fundação Getúlio Vargas FGV, Desenvolvimento Gerencial na IESE Business School - Universidade de 
Navarra, possui pós-graduação em Gestão Estratégica pela Fundação Instituto de Administração - FIA, MBA internacional em Programa de Gestão pela Euromed Marseille (França), MBA em Tecnologia da Informação pela Universidade de São Paulo - USP e pós-graduação em Negócios Internacionais pela Universidade Presbiteriana Mackenzie.

A entrevista foi realizada na cidade de São Paulo, durante um almoço, em um restaurante da Avenida Cidade Jardim. Tive a oportunidade de trabalhar como auditor interno na equipe da Renata durante todo o ano de 2017. Renata se sentiu lisonjeada quando apresentei a ela as respostas do questionário e informei que ela é considerada uma referência em gentileza. Falei que, mesmo após dezoito meses desde que ela foi transferida para o $\mathrm{BBI}$ e deixou de trabalhar no Departamento de Auditoria Interna, é comum eu presenciar as pessoas lembrarem dela com alegria e reviver histórias, buscando inspiração de como conduzir situações e atividades, por mais complexas que sejam e verbalizei que Renata é uma pessoa que faz falta. Exemplifiquei, à Renata, que eu soube por terceiros que, meses após sua transferência, ela enviou flores no dia do aniversário da funcionária que faz a limpeza do departamento.

Algumas das minhas colegas de trabalho também já me contaram alegremente que receberam flores da Renata no dia dos seus aniversários. Dei vários outros exemplos à Renata de histórias que vivi e escutei sobre a gentileza dela. Renata permanecia sorrindo ao ouvir de mim que a semente da gentileza que ela plantou entre os que trabalham no Departamento de Auditoria Interna brotou e continua crescendo. Recordei e comentei que, na ocasião em que ela assumiu a superintendência da auditoria de negócios, com aproximadamente 150 profissionais, entre eles auditores, coordenadores e gerentes de auditoria, ela chamou um por um para uma conversa amistosa, um verdadeiro bate-papo, para conhecer melhor o funcionário e vice-versa. Nosso diálogo durou mais de duas horas e outros colegas e amigos também comentaram sobre o bate-papo deles com a Renata. Todos nos sentimos alegres, valorizados e confiantes ao notar a liderança gentil da nova superintendente. Ali ela começou a engajar e inspirar seus liderados. Após comentar e relembrar tais gentilezas, começamos efetivamente a entrevista: 
Rafael - Renata, alguém te inspirou a ser gentil? Se sim, quem?

Renata - Bom, eu posso dizer que eu fui inspirada pela minha mãe. A minha mãe é uma pessoa muito gentil eu acho que eu herdei isso muito dela. Ela é uma pessoa muito calma e passa uma tranquilidade em fazer as coisas com carinho, de modo que se ela te encontrar aqui agora ela vem e te dá um beijo, passa muito carinho. Então, eu posso afirmar que eu sou quem eu sou por causa de minha mãe.

Rafael - Então veio de berço...

Renata - Sim, veio de berço! A minha mãe já trabalhou em creche, Rafael, todas as crianças da creche queriam ir embora com ela. Um dia um pai Ihe falou assim: "eu sei que a senhora deve ser a melhor mãe do mundo, porque se meu filho que ir embora com a senhora é porque a senhora trata ele muito bem, então eu fico tranquilo". E é verdade! Porque ela trata qualquer criança como se fosse filho. Minha mãe é assim em tudo o que faz e passa isso muito bem para mim e para minha irmã. É muito querida em tudo o que faz e, também, com as pessoas, porque tem esse jeito doce.

Rafael: Como se todos ao seu redor fossem seus filhos?

Renata: Exatamente.

Rafael: Talvez seja isso que falte hoje nas empresas...

Renata: Talvez... É um pouco também de se enxergar no lugar da outra pessoa, pois ninguém quer ser maltratado, ninguém erra de propósito. Você consegue ver se a pessoa tem uma má índole ou não. Então é bem isso: só erra quem trabalha... Se uma pessoa tentou fazer o melhor e não deu certo, eu vou punir?! Será que esse é o caminho que eu deveria seguir? Ou eu deveria incentivar dizendo "vamos arrumar juntos"? Colocar-se no lugar do outro para mim é fundamental, porque todo mundo quer ser bem tratado, todo mundo quer atenção, mas dificilmente isto é priorizado. Este é o ponto.

Rafael: O que é gentileza para você? 
Renata: Para mim, gentileza se define por amor. Amor pelo que você faz, é ter compaixão pelo outro... Gentileza é um conjunto de coisas, ela não se define numa única palavra, ela se define num todo.

Rafael: Na sua visão, a gentileza pode trazer maiores resultados financeiros e produtividade para as empresas?

Renata: Pode sim, dependendo da forma como você coloca as coisas e mostra. Sabe aquela história de fazer do limão uma limonada? Então, o limão é azedo, mas dependendo da forma como você o utiliza, ele deixa tudo muito gostoso e dá um toque especial. Mesmo aquela pessoa amarga e eu costumo dizer que o mais gostoso é trabalhar justamente com aquela pessoa que é mais difícil. Sabe aquela pessoa que é do contra? É a experiência mais gostosa porque é com ela que você tem que trabalhar para ajudá-la a mudar. Certa vez eu tive um colaborador muito rude, ofereci um coaching a ele e disse: eu quero que você mude, não por que eu estou pedindo para você mudar, mas eu quero que você mude porque você tem um filho pequeno, e, quando ele for adolescente, você terá que ter muito jeito para lidar com ele e se você for lidar com ele com a rispidez que você tem hoje, você não vai ganhar seu filho. Você tem que ser amigo dele quando ele for adolescente, para ele te contar as coisas, para você saber com quem ele está andando... Então, eu quero que você mude não por mim, eu quero que você mude porque você quer mudar, porque você entende que ser da forma como eu estou te propondo, mais gentil, entendendo melhor cada pessoa, vai trazer mais resultados para o seu trabalho. Então, com gentileza, se consegue tirar mais frutos das pessoas. Vou dar o exemplo de quando eu trabalhava na auditoria: em muitas vezes precisei fazer trabalho em dia de sábado, domingo ou ficar a noite após o horário. Nunca alguém se negou a me ajudar no trabalho, aliás, às vezes, eles competiam entre si pra me ajudar dizendo "deixa que eu vou, Renata, deixa que eu vou" e eu respondia "não, você já ficou após o horário da outra vez, deixe eu ver com outra pessoa".

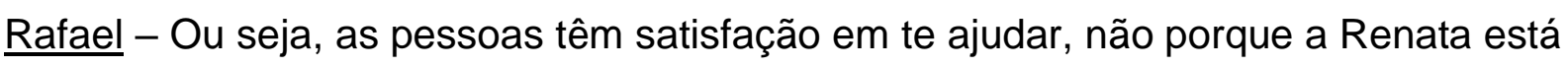
mandando, mas porque a Renata está precisando... 
Renata - Sim, é porque eu estava precisando. Eles sabiam disso e iriam me ajudar. Eu não preciso impor, eu não preciso dar carteirada e as pessoas perguntavam para mim: "Renata, você é auditora mesmo?" Eu respondia: "sim, sou, mas não preciso dar carteirada para conseguir as coisas", até mesmo porque, Rafael, na carteirada a gente consegue que a pessoa faça o que se está pedindo, mas ela fará furiosa, só para me entregar e eu sair do seu pé e na próxima vez que eu tiver que fazer um trabalho com essa pessoa ela vai dificultar a minha vida. Agora, se eu the mostrar uma parceria e que, como auditora, eu estou ali para ajudar e muitas vezes ser os seus olhos, para ver coisas que ela não consegue enxergar, mas que eu, que não estou no dia a dia consigo, nessa parceria, vou conseguir agregar muito mais valor do que se eu for auditar com rigidez. Então, para mim, esta é a grande diferença em promover as coisas, você pode dar um tapa com luva de pelica ou você pode dar um tapa na cara, tem gente que te dá um tapa com luva de pelica e você ainda agradece, por que você para e pensa "poxa, é verdade" e você vai agradecer porque eu vou abrir seus olhos sobre algo que talvez não estivesse enxergando. Muitas das vezes a gente não aprende no amor, a gente aprende também na dor e eu consigo te passar a mesma mensagem com gentileza ao invés de passar com rispidez, mas você ficaria muito bravo a ponto de parar de escutar o que eu estou falando, mas tenho a opção de poder falar com toda a gentileza do mundo e você concluir "poxa, ela tem razão!".

Rafael - Renata, você tem uma carreira de notório sucesso: é diretora da $3^{\text {a }}$ maior empresa de capital aberto do Brasil e 68ำ maior banco do mundo. Você considera que a sua gentileza contribuiu para você chegar até aqui?

Renata - Sim, acho que foi um diferencial, tenho vários colegas da mesma forma, mas as pessoas me ajudaram e não precisei me impor para isso. Então, continuo com essa receita, pois acho que é uma receita de sucesso, acredito que, com a gentileza, a gente passa a mensagem, quando tem que ser brava, sou brava, mas também sei reconhecer, sei quando algo foi demais e peço desculpa e esse conjunto faz toda a diferença. Eu não cheguei sozinha, cheguei com todas as pessoas que me apoiaram e a minha gentileza gerou todo esse apoio. Ela deu a base para as pessoas irem me ajudando. Ninguém faz nada sozinho, se alguém nesse mundo acha que chegou a 
qualquer lugar sozinho, este alguém está muito errado. Pode até ser que muita gente não concorde com meu jeito, Rafael, e já escutei isso de pessoas. Mas sou a Renata no banco e sou a Renata na minha vida particular, não mudo sendo uma Renata aqui e outra lá fora. Eu sou o que eu sou e mesmo que algumas pessoas não me olhem bem, eu considero que a gente consegue melhor as coisas dessa forma.

Rafael - Você poderia compartilhar um episódio marcante em sua carreira envolvendo a gentileza?

Renata - Teve vários. Um marcante foi envolvendo uma pessoa que por conta das sucessivas grosserias que praticava, estavam desistindo dela, mas eu assumi a responsabilidade de ajudá-la, pois notei que essa pessoa, apesar de ter muito conhecimento técnico e de entregar excelentes resultados financeiros, teve péssimos exemplos na vida, e, assim, estava replicando padrões de comportamentos ruins aprendidos durante sua carreira, como maltratar e humilhar as pessoas. Recordo de quando conversei com essa pessoa sobre o assunto e disse que the deram a missão de conduzir um transatlântico até o porto e ela fez isso, conduziu o transatlântico até o porto e cumpriu a entrega, contudo a tripulação chegou morta, porque ela matou todo mundo com palavras, com ações, com atitudes, com tudo de errado que ela fez. Então, por um lado, ela tinha méritos e por outros tinha deméritos porque matou todo mundo, só que ninguém falou que ela tinha que chegar com a tripulação viva. Após isso ela fez coaching e, com o tempo, melhorou seu comportamento, continuou a entregar bons resultados financeiros, mas sem maltratar as pessoas. Ela aprendeu que é possível comemorar com todos a chegada do transatlântico no porto, com a equipe viva e satisfeita. A falta de gentileza tinha lhe roubado a possibilidade e o prazer de comemorar a vitória com a equipe. Essa para mim foi uma grande vitória, pois as pessoas da equipe comentam até hoje o quanto essa pessoa mudou e melhorou e isso para mim é gratificante. E essa pessoa sabe até hoje que eu sempre vou pregar a gentileza! Eu não sei se um dia essa será a sua essência, mas ela teve a oportunidade de provar das duas coisas, uma entrega rude e uma entrega gentil. Aí é uma escolha, de qual caminho ela vai achar melhor para ter durante a vida. $\mathrm{Na}$ época, considerei que no contexto em que essa pessoa ingressou no mercado de 
trabalho a regra era ser rude e, provavelmente, ela teve que ser rude por uma questão de sobrevivência naquele contexto. Talvez ela não tenha tido alguém para ensiná-la as vantagens de trabalhar e viver com gentileza. Eu acredito nas pessoas e esse foi um trabalho de sucesso. Não podemos desistir das pessoas.

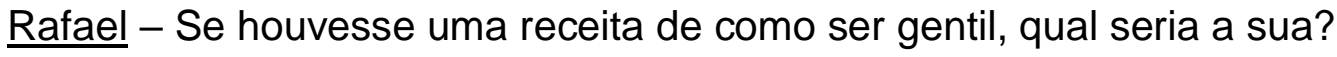

Renata - Agora você me pegou... (risos) é como a ética, a gentileza é como a ética, você tem que praticar todos os dias. Quando a gente está numa fila, eu vejo você na frente e vou conversar com você só para passar, eu não fui ética, tinham várias pessoas atrás de mim. Concorda?! Uma coisa aprendi com a gentileza: você pode estar furioso, mas a outra pessoa não tem nada a ver com isso. É uma prática diária, você sempre tem que se colocar no lugar da outra pessoa e falar "eu iria querer isso pra mim?", se você não iria querer, não faça para o outro. A receita é praticar todo dia e se colocar no lugar do outro. Às vezes a gente fica furioso quando recebe ligação de telemarketing, temos a mania de já sair querendo chutar, mas eu penso "poxa vida, essa pessoa precisa vender, é o trabalho dela" então porque não responder "muito obrigada, entendo, mas hoje eu realmente não estou interessada", do que sair gritando "não me ligue mais, você já me ligou antes!"

Rafael - A pessoa não vai ficar chateada por não ter feito uma venda, a pessoa vai ficar chateada por ter sido maltratada.

Renata - Isso mesmo. É por isso que muitas empresas de telemarketing possuem sala de descompressão. Às vezes as pessoas vão lembrar só daquela parte ruim, quantas pessoas já não foram maltratadas, né? Quantas pessoas ligam no final do ano bem no natal ou no ano novo, bem na virada, para conversar pois não tem ninguém e queriam conversar com alguém...

Rafael - Já ouvi histórias assim...

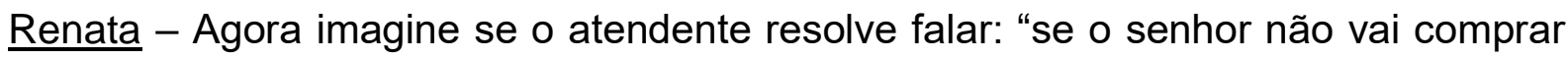
nada então vamos desligar, pois eu preciso vender", entendeu? Às vezes você salva a vida de alguém que precisava só de uma palavra de carinho ou só ser escutada. 
Então, esta é a diferença da gentileza e ela cai bem em qualquer lugar. Todos nós vamos morrer um dia, isso é fato. Se alguém disser que vai viver eternamente, não vai. E aí, por que não deixar coisas boas, né? Nós vamos todos para o mesmo lugar e qual é a diferença entre uma pessoa que faz a limpeza, um auditor, um diretor e um presidente?! Então olha que bonito quando você vê alguém que não enxerga essa distinção. Por que distinção? Por que você é melhor que o outro? É a mesma coisa de um cara que está com uma ferrari e outro com um fusquinha, os dois vão chegar no mesmo lugar, um talvez chegue com um pouco mais de conforto ou mais rápido porque o carro é mais potente, mas o fusquinha vai chegar lá também. É só questão de ponto de vista, da forma de olhar e, se você notar, verá que é a mesma coisa. $E$ você tem a oportunidade de escolher.

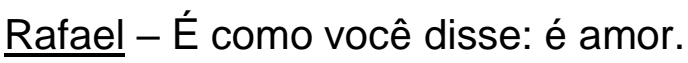

Renata - Sim, gentileza é amor.

A entrevista exemplificou muito do que foi mencionado no referencial teórico e no questionário respondido pelas cem pessoas. O fato de a Renata ter como inspiração de gentileza a sua própria mãe, que trabalhava em creche, reforçou a importância de se estimular a gentileza desde criança, situação destacada por Rodrigues (2019) ao mostrar o projeto da pedagoga Gisele Masotti. Uma criança estimulada a ser gentil pode vir a se tornar uma referência em gentileza na fase adulta, no mercado de trabalho, produzindo excelentes resultados financeiros de forma humanizada, e promovendo, também, felicidade para si própria e para os colegas de trabalho. Quando Renata defende que colocar-se no lugar do outro é fundamental, porque todo mundo quer ser bem tratado, todo mundo quer atenção, mas dificilmente isto é priorizado, ela está alinhada com o conceito de empatia trazido pelo neurocientista O'Connor (2018), que explica que a empatia conecta emocionalmente as pessoas por meio dos neurônios-espelho.

Renata corrobora, também, com Tiago (2015), que afirma que se colocar no lugar do outro torna as coisas muito mais fáceis e salienta que todos temos que conhecer a definição da palavra empatia e multiplicá-la. A Renata, na condição de diretora de 
banco e ao mesmo tempo referência em gentileza, mostra, na prática, a afirmação de Harrison (2007), de que é perfeitamente possível ter os privilégios inerentes ao cargo de executivo mantendo boas relações de cordialidade, educação, respeito, empatia e compaixão pelos gerentes e colaboradores comuns, comprovando que há executivos que desdenham a arrogância executiva e nem por isso são líderes menos eficientes. O conceito de gentileza trazido por Renata, de seu amor pelo que se faz, compaixão pelo outro, não se definindo numa única palavra, mas em um conjunto de coisas, complementa o conceito do educador Mário Sérgio Cortella.

Ele afirma que a gentileza precisa e pode ser aprendida, ensinada, praticada, protegida e partilhada a partir de uma série de ações que temos que exercer em nosso cotidiano. Amor e compaixão inevitavelmente utilizam-se de ações gentis para serem aprendidos, ensinados, praticados e partilhados. Harrison (2007) afirma que as gentilezas colocam valores em prática, então podemos concluir que gentileza é amor em movimento. Tiago (2015), afirma que o uso de gentilezas melhora os resultados. Renata e $98 \%$ dos respondentes do questionário consideram que a gentileza pode trazer maiores resultados financeiros e produtividade para as empresas e Renata explica o motivo: por meio da gentileza as pessoas entregam mais de si mesmas, voluntariamente e alegremente, resultando em entregas melhores.

Melo (2017) complementa a explicação de Renata ao mostrar um conceito muito gentil e produtivo de liderar: é dar uma boa causa pela qual as pessoas queiram lutar, em qualquer área da vida, contribuindo e criando maneiras de as pessoas fazerem coisas extraordinárias acontecerem. Ao fazê-lo, o líder conseguirá que, alegremente, as pessoas realizem o que normalmente sofreriam para fazer, ou seja, trabalhar em nível de superação. Sobre o episódio marcante compartilhado pela Renata, envolvendo o uso de gentileza, Tiago (2015) salienta que a humanização movimenta uma equipe de forma favorável com resultados que fazem um líder ser lembrado como um gestor que fez por merecer a posição que ocupa. Conforme a Renata destacou, a gentileza é um diferencial de carreira e cai bem em qualquer lugar. Para isso é necessário decidir diariamente praticá-la, não desistindo das pessoas e pregando sempre a gentileza. 


\section{CONCLUSÃO}

Com as pesquisas teóricas e empíricas realizadas, seguramente, pode-se afirmar que a gentileza, perante os mais diversos desafios que as pessoas enfrentam no meio corporativo, é uma ferramenta para se humanizar as relações, garantindo mais bemestar e felicidade às pessoas bem como melhores resultados financeiros e produtividade às empresas. Os conceitos discutidos indicam que a gentileza é uma forma particular de pensar para agir em convivência, cujas ações evitam, em si próprio e no outro, dano, tristeza ou incômodo. Os tipos de gentilezas, as formas como podem ser empregadas e, principalmente, os resultados que proporcionam indicam o quanto é gratificante e produtivo se investir nesta forma de amar a si mesmo e as demais pessoas.

A pesquisa empírica, por meio do questionário aplicado e da entrevista realizada, trouxe a comprovação do que os autores citados afirmam: de que a gentileza é um excelente negócio e que há vasto campo para aplicação. As pessoas desejam cada vez mais felicidade e bom tratamento, ao mesmo tempo as empresas anseiam por resultados cada vez melhores, e esses desejos podem ser realizados. Já pensou em fazer as pessoas se sentirem mais felizes e ainda ganhar mais dinheiro com isso? O uso da gentileza torna isso possível. O impacto da gentileza nas empresas vai muito além de agradar as pessoas. É necessário muita dedicação, planejamento, persistência e paciência para se cultivar diariamente a gentileza.

Dessa forma, é preciso optar, e, assim, aderir, de modo constante, ações gentis. Em troca, recebe-se sorrisos, alegrias, felicidades, bem-estar, engajamento e envolvimento das equipes e melhores entregas, produtividade e resultados mais eficientes. Isso é tão possível que a pesquisa teórica mostrou muitas formas de se estimular a gentileza no ambiente organizacional e mostrou, ainda, como influenciar as futuras gerações de profissionais a serem mais gentis. A gentileza se mostra como o motor para o crescimento das pessoas e acelerador da eficiência das empresas, com custo mínimo, sem contra indicações, bastando boa vontade para utilizá-la. 


\section{REFERÊNCIAS}

ARAÚJO, M. A. A. Etiqueta empresarial: ser bem educado é... Rio de Janeiro: Qualitymark, 2004.

BARROS, C. Shinsetsu - o poder da gentileza. São Paulo: Editora Planeta do Brasil, 2018.

BRANDÃO, D. M. Liderança que valoriza pessoas - pratique Giftworks. 2017. Disponível em: https://noticias.ne10.uol.com.br/coluna/doses-defoco/noticia/2017/11/08/lideranca-que-valoriza-pessoas-\%E2\%80\%93-pratiquegiftworks-721287.php. Acesso em: 04 ago. 2019.

BRASIL. Câmara dos Deputados. Rádio Câmara - a música do dia (13.11.2015). Disponível em https://www2.camara.leg.br/camaranoticias/radio/materias/A-MUSICADO-DIA/456932-DIA-MUNDIAL-DA-GENTILEZA.htmI. Acesso em: 22 jun. 2019.

BREMER, M. Appreciative inquiry to build a culture of kindness. 2015. Disponível em: https://www.leadershipandchangemagazine.com/appreciative-inquiry-to-build-aculture-of-kindness/. Acesso em: 22 jun. 2019.

COMPARATO, F. K. Ética: direito, moral e religião no mundo moderno. São Paulo: Companhia das Letras, 2016.

CURRY, O. S. et al. Happy to help? A systematic review and meta-analysis of the effects of performing acts of kindness on the well-being of the actor. 2018. Charlottesville (EUA). Center for open science. Disponível em: https://osf.io/ytj5s. Acesso em: 18 jun. 2019.

FERREIRA, L. A arte de ser leve. São Paulo: Editora Planeta do Brasil, 2018.

GUELMAN, L. 0 profeta gentileza. Disponível em: http://www.riocomgentileza.com.br/index-2.html. Acesso em 13 jun. 2019. 
HARARI, Y. Sapiens: uma breve história da humanidade. Porto Alegre: Editora L\&PM, 2015.

HARRISOM, S. Manual de gentilezas do executivo. São Paulo: Primavera Editorial, 2007.

HASKINS, G.; THOMAS, M.; JOHRI, L. Kindness in leadership. Abingdon, Oxon (Inglaterra): Editora Routledge, 2018.

MELO, P. A. A. Liderança na era da hipercompetitividade. São Paulo: Editora Laços, 2017.

O'CONNOR, B. The neurobiology of the kindness: inside the brain. 2018. Disponível em: https://inside-the-brain.com/2018/11/13/the-neurobiology-of-kindnessworldkindnessday/. Acesso em: 22 jun. 2019.

RODRIGUES, L. Professora de Jundiaí ganha prêmio com projeto que ensina gentileza a alunos. Tribuna de Jundiaí. 2019. Disponível em: https://tribunadejundiai.com.br/educacao/escola-inovadora/professora-de-jundiaicria-projeto-para-ensinar-gentileza-aos-alunos/. Acesso em: 04 ago. 2019.

STURT, D.; NORDSTROM, T. How purposeful kindness can make you a better leader. $2018 . \quad$ Disponível em: https://www.forbes.com/sites/davidsturt/2018/10/24/how-purposeful-kindness-canmake-you-a-better-leader/\#4555f2397b7a. Acesso em: 22 jun. 2019.

TAYLOR, B. Making kindness a core tenet of your company. 2018. Disponível em: https://hbr.org/2018/11/making-kindness-a-core-tenet-of-your-company. Acesso em: 22 jun. 2019.

TIAGO, L. G. Gentileza no trabalho: conciliando sua vida pessoal com a profissional. São Paulo: Editora Ideias e Letras, 2015.

Enviado: Dezembro, 2019. 
Aprovado: Março, 2020. 